IRA-International Journal of Education \& Multidisciplinary Studies

ISSN 2455-2526; Vol.04, Issue 01 (2016)

Institute of Research Advances

http://research-advances.org/index.php/IJEMS

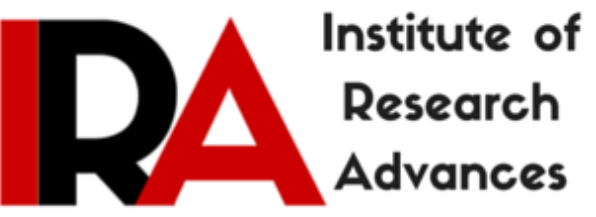

\title{
Understanding School Feeding Programmes in India and Tamil Nadu in addressing Classroom Hunger
}

Dr. Anbu Arumugam, Assistant Professor, Department of Public Administration, Annamalai University, India (Young Scholar 2013; Founders Fellow 2014)

DOI: http://dx.doi.org/10.21013/jems.v4.n1.p4

\section{How to cite this paper:}

Arumugam, A. (2016). Understanding School Feeding Programmes in India and Tamil Nadu in addressing Classroom Hunger. IRA International Journal of Education and Multidisciplinary Studies (ISSN 2455-2526), 4(1).

doi:http://dx.doi.org/10.21013/jems.v4.n1.p4

(C) Institute of Research Advances

(cc) EY-NC

This works is licensed under a Creative Commons Attribution-Non Commercial 4.0 International License subject to proper citation to the publication source of the work.

Disclaimer: The scholarly papers as reviewed and published by the Institute of Research Advances (IRA) are the views and opinions of their respective authors and are not the views or opinions of the IRA. The IRA disclaims of any harm or loss caused due to the published content to any party. 


\section{ABSTRACT}

Despite primary schooling being universally recognized as a public good, with a direct impact on economic growth, one billion people in the world - on in six - are illiterate, and 104 million of the world's children were out of school in the year 2013 (United Nations Economic, Social, and Cultural Organization [UNESCO] 2013). Over third of the world's illiterates are in India. India's population of illiterates is larger than that of any other country in the world - at least 350 million people, according to 2011 Census of India. In other words, more than one in three illiterate persons on the planet is an Indian and India's population of illiterates in 2010 was larger than the total population of the country in 1947. Well-designed and effectively implemented social protection programmes are essential for ensuring access to food and comprehensively addressing the problem of malnutrition. These programmes are noncontributory and sharply targeted programmes that focus on the poor and vulnerable sections of the population. Among many social protection programmes in India there are two broad categories specifically targeted for the poor and closely related to food security and nutrition. These are (i) Public Distribution System and Supplementary Nutrition Programmes and (ii) Rural Wage Employment Programme. The Integrated Child Development Services (ICDS) and the Mid-Day Meal Scheme (MDMS) are two major initiatives for improving the level of nutrition.

Keywords: Food Security, Social Protection, Mid-day Meal Scheme, Children, Classroom Hunger, Malnutrition, Public Distribution System

\section{Background:}

School feeding programs have been defined by the World Bank as "targeted social safety nets that provide both educational and health benefits to the most vulnerable children, thereby increasing enrollment rates, reducing absenteeism, and improving food security at the household level." Beyond improvements in access to food, school feeding programs also have a positive impact on nutritional status, gender equity, and educational status, each of which contributes to improving overall levels of country and human development. While there are school feeding programs in a number of countries, each program varies widely from country to country in design, implementation, and evaluation. Thus, literature reviews and studies often focus on a small number of countries, as school feeding is not a uniform unit of intervention and cannot be compared or assessed on an international scale. There are as many types of programmes as there are countries, but they can be loosely classified into two main groups: (1) in-school feeding, where children are fed in school with (a) programmes that provide meals; and (b) programmes that provide high-energy biscuits or snacks; and (2) take-home rations, where families are given food if their children attend school regularly.

In this regard the state of Tamil Nadu pioneered a vision of a Mid-Day Meal Scheme (MDMS) as part of a nutritional supplementation, which has been fitted into the educational and health policy gradually over the past few decades. The noon meal scheme cam to be recgonised as a successful incentive in registering regular attendance of pupils enrolled in the school system run by the government also known as government schools or public schools. It also helped to increase the enrollment in rural areas of Tamil Nadu. Pupils of different communities sat together and ate together. Thus, it helped to break the caste barrier and led to a silent revolution. One of the major factors in preventing rural parents in sending their wards to schools was their inability to feed them regularly. At least one meal provided in the school in the afternoon has the possibility of increase in enrollment in schools. The scheme brought about a significant change in the social environment in rural and backward areas in the state of Tamil Nadu in India. Tamil Nadu's pioneering Mid-Day Meal Scheme is now acclaimed internationally as a welfare project.

\footnotetext{
1 "Scaling Up School Feeding" (http://web.worldbank.org/WBSITE/EXTERNAL/TOPICS/EXTEDUCATION),The World Bank and World Food Programme, 2012
} 
Policies to tackle hunger need dovetailing of the longer-term perspective, in the form of empowering of the poor and improving their entitlements through investment in human capital, with the social protection measures that address the immediate needs of the hungry and the malnourished. There is scope for well implemented government programmes so that access to sanitation, potable water and health facilities in a timely manner helps in the consolidation of the gains from improved entitlements to food and nourishment. Two key problems relating to children in India are the large numbers of children out of school and the considerable extent of under-nourishment among children. In 2004, around 15 per cent of children in the age group of 6-14 years were out of school (Right to Food Campaign, 2006). According to the third national family health survey (NFHS 3, 2007) which has 2005-06 as its reference period, 46 per cent of India's children fewer than 3 years of age are underweight. The corresponding figure is 30 per cent in Sub-Saharan Africa while China records 8 per cent and Pakistan 37 per cent (Lal, 2007). India was home to 57 million - or more than a third - of the world's 146 million undernourished children (NFHS 3, 2007). The policy challenge, in this context, is to address both the educational needs and the nutritional needs of the children in the school-going age group.

\section{Need for school feeding programs}

According to the United Nations World Food Programme, 66 million primary school age children go hungry every day, with 23 million hungry children in Africa alone. ${ }^{2}$ Furthermore, $80 \%$ of these 66 million children are concentrated within just 20 countries. Additionally, 75 million school-age children (55\% of them girls) do not attend school, with $47 \%$ of them living in sub-Saharan Africa. ${ }^{3}$ Thus, the need to reduce hunger while increasing school enrollment in these children is evident, and school feeding programs have been developed to target this multifaceted problem. Schools have become a natural and convenient setting for the implementation of health and education interventions. School feeding is just one facet of school health initiatives, as other programs may include de-worming, HIV/AIDS prevention and education, and life and health skills education. Additionally, school feeding directly addresses the Millennium Development Goals (MDGs) of reducing hunger by one-half, achieving universal primary education, and achieving gender parity and equity in education by $2015 .^{4}$

\section{Approaches to school feeding}

According to the International Food Policy Research Institute, there are five stages of school feeding. The first stage includes school feeding programs that rely mostly on external funding and implementation, while the last stage includes school feeding programs that rely mostly on internal government funding and implementation. ${ }^{5}$ Countries that are within the first stage include Afghanistan and Sudan, where country governments are unable to lead school feeding programs. Countries that are within the fifth stage include Chile and India, which have functional, country-led school feeding programs. For example, the Government of Chile has provided a school feeding program for over 40 years through the La Junta Nacional de Auxilio Escolar y Becas (National Board of School Assistance and Scholarships) through a public-private partnership. ${ }^{6}$ This program involves technology that allows food to be centrally mass-produced and then distributed across the country. Additionally, the Government of India has supported school feeding programs since 2001, when the country recognized Indians' Constitutional Right to Food. United Nations World Food Programme (WFP) is the world's leading

\footnotetext{
2 "School Meals" (http://www.wfp.org/school-meals) World Food Programme, 2009

3 "Education" (http://web.worldbank.org/WBSITE/EXTERNAL/EXTABOUTUS) The World Bank,2013

4 "Millennium Development Goals" (http://www.un.org/millenniumgoals/) The United Nations, 2013

${ }^{5}$ Bundy, Donald (2009). "Rethinking School Feeding - Directions in Development Paper", (http://www.ifpri.org/sites/default/files/DBundyppt.pdf), International Food Policy Research Institute

${ }^{6}$ Winch, Rachel (2011) "International Approaches to School Feeding" (http://foodaid.org/news/wpcontent/uploads/2011/01/Rachel_Winch_International_Approaches to_School_Feeding.pdf), US Food Aid and Security
} 
provider of school feeding program financial contributions and program development. The World Food Programme has estimated that US\$3.2 billion is needed each year to feed the 66 million school-age children around the globe, an amount of US\$50 per child. ${ }^{7}$

\section{Benefits of school feeding}

1.) Nutrition and food security: The amount of kilocalories in a child's diet is expanded when they are given nutritional resources that they would otherwise have little to no access to. ${ }^{8}$ The problem in terms of nutrition delivery needs to be addressed via high food prices, access to food and public distribution systems in each country.

2.) Education: Generally, sending children to a school in which school-meals are served offsets the financial and opportunity costs of schooling, and thus families are incentivized to send their children to school. Classroom hunger is hugely addressed by the School Feeding Programs. The program also enhances students' cognitive abilities and performance in school.

3.) Gender and Social Equity: The access to education for girls is greatly generated by school feeding programs by allowing for gender parity and social equity in schools. In a patriarchic society such as India gender-stereotyped curriculum and teaching practices, increased risks for girls' safety outside of the house, socio-cultural practices that cause girls' education valuless, and lack of toilets for girls etc. are reasons for lack of access to education for girl children. ${ }^{9}$ Improvements in female literacy that come from increased education have been linked to declining rates of fertility, increased economic opportunities, and other markers of female empowerment. Social equity is visible in these schools where caste, community, religious barriers are removed while eating, playing and studying together. These are major improvements in countries such as India where social equity is a huge challenge even after 66 years of independence.

\section{Challenges to School Feeding Programme:}

The provision of essentials and consistent service-delivery to the ever increasing population does pose a major challenge in the continuous constant of delivering the school meal by countries in the middle-income and low-income groups. International funding model is a good alternative but that may be invasive and may come with conditional implementation with the internal structure of the countryspecific program structure. Civil society participation is also an alternative solution. In India the program is tied to the budget planning and a ministry set-up centrally under the Ministry of Human Resources Development, takes care of the overall implementation, monitoring mechanism and financial planning and allocation for the Mid-Day Meal Scheme.

For example, school feeding programs can increase the cost of schooling by requiring that communities provide fire-wood for cooking as well as other items such as fresh-fruit, vegetables, and condiments. Additionally, communities are also expected to provide people who can cook these meals and maintain stores of all of the required food products, as well as kitchens and other fundamentals of meal provision. School feeding programs are very context-specific, and each community's program has to be altered based on the demographics, geography, and other patterns within and outside of schools. For this reason, there are a variety of challenges that emerge in the creation and implementation of school feeding programs. In order to have a successful program, countries must determine if school feeding is the

\footnotetext{
7 "School Meals" (http://www.wfp.org/school-meals) World Food Programme, 2009

${ }^{8}$ Lawson, Ty M (2012) "Impact of School Feeding Programs on Educational, Nutritional, and Agricultural Development Goals" (http://ageconsearch.umn.edu/bitstream/142466/2/2012LawsonPlanB.pdf) Michigan State University

${ }^{9}$ Ahmed, Touseef et al. (2007) "Food for Education Improves Girls' Education: The Pakistan Girls' Education

Programme",Schools and Health
} 
most effective program that can be offered to target the countries' neediest children, define program goals and outcomes, select the type of food that will be served in a school, determine a method of procurement for the food, plans for management, implementation, and monitoring within schools, and plan for a variety of other concerns. ${ }^{10}$ The sustainability of school feeding programs is a main point of concern for many countries.

\section{Mid-day Meal Scheme (MDMS) - The India Story:}

The Mid-day Meal Scheme (MDMS) is a flagship programme of the Government of India, initiated in 1995 (in 2408 select blocks) with the objective of enhancing enrolment, retention and attendance at the primary school level, and also to simultaneously improve nutritional levels among children studying in government and government-aided schools. It is expected to improve their learning ability. Since 1997-'98 it has been universalized, and from 2008-'09 onwards even the upper primary school level has been brought under this programme. Initially, only dry rations were being distributed under the programme, but from 2002 provision for cooked mid-day meal in schools have been made under the direction of the Supreme Court of India. Under this scheme, for children studying at the primary level, 450 calories and 8-12 grams of protein are provided per day. In case of upper primary students, the provision has been fixed at a minimum of 700 calories and 20 grams of protein per day. A freshly cooked meal offers a better range of nutrients and packaged food is costlier, per rupee nutrient yield.

Dreze and Goyal (2003) observed that while MDMS has many flaws, it supports improved school attendance, and to a large extent eliminates classroom hunger in the schools investigated. One of the important indirect benefits of MDMS is in undermining caste prejudice, thereby contributing to strengthening of cohesion and equity in the society. One of the important drawbacks of this programme is the lack of infrastructure like storage facility, cooling shed and utensils. In some places teachers and students have to often spend a considerable amount of time preparing meals, rather than focusing on school curricula (Khera 2006).

In terms of corrective measures there is a need for a substantial increase in financial allocation to this programme given its potential impact. Adequate nutrition in the form of pulses and vegetables can be introduces in the school meals. Increasing financial allocation can also support appointment of staff for procurement, cooking, distribution of cooked meals, and maintaining proper cleanliness and hygiene. At the State level, designated officers need to be put in place exclusively for this programme. There is a case for encouraging the civil society and private participation in setting up centralized cooking facilities at block headquarters. This is being done in Churu district of Rajasthan and Vishakhapatnam in Andhra Pradesh in a Private-Public Partnership (PPP) mode (Government of India, 2010). It can significantly reduce hurdles and difficulties in supervising the programmes for cleanliness, hygiene and maintaining the nutritional standards. At the same time, prevent the teaching and studying time of teachers and students from being compromised respectively.

\section{Policy Development of Mid-Day Meal Scheme in India and Tamil Nadu:}

The right to food is important and it is directly related to the non-derogable right to life that is the foundation of all rights. There is no explicit provision for the right to food in the Constitution of India. However, the issue of right to food gained wider attention when the Supreme Court of India intervened through a writ petition filed by the PUCL (People's Union for Civil Liberties) against the Union of India, Food Corporation of India, and six state governments under Public Interest Litigation (PIL) in the year

\footnotetext{
10 "Scaling Up School Feeding" (http://web.worldbank.org/WBSITE/EXTERNAL/TOPICS/EXTEDUCATION) The World Bank and World Food Programme, 2012
} 
2000. ${ }^{11}$ Responding to the Writ Petition the Supreme Court interpreted the Article- 21 in wider sense and delivered its historic judgment in 2001. In this judgment, the Supreme Court directed all state governments in India to provide cooked meal instead of dry ration to all primary school going children. The apex court asked the government to incorporate the right to food as an essential element in the policy making process. Expressing seriousness over the starvation deaths in Orissa, Rajasthan, Madhya Pradesh and growing food insecurity and the state's inaction, the Supreme Court directed to take immediate actions for the free distribution of food grains to the needy instead of storing and wasting it in the state government-owned warehouses and the Food Corporation of India (FCI). The Supreme Court also held the view that priority has to be given to those who are neither able to go for employment nor have the capacity to demand from the State. In this connection, on November 23, 2001, the Court directed all the state governments to implement nearly eight food security schemes. ${ }^{12}$

In subsequent orders, the Supreme Court further strengthened the right of children to a mid-day meal at school. In its orders of 20 April 2004, the Court observed, inter alia, that:

- 'The conversion costs for a cooked meal, under no circumstances, shall be recovered from the children or their parents'.

- 'The Central Government... shall also allocate funds to meet the conversion costs of food-grains into cooked mid-day meals'.

- 'In drought affected areas, mid-day meals shall be supplied even during summer vacations'.

- 'In appointment of cooks and helpers, preference shall be given to Scheduled Castes and Scheduled Tribes'.

- 'The Central Government shall make provisions for construction of kitchen sheds'.

- 'Attempts shall be made for better infrastructure, improved facilities (safe drinking water etc.), closer monitoring (regular inspection etc.) and other quality safeguards as also the improvement of the contents of the meal so as to provide nutritious meal to the children of the primary schools'. These are some of the

${ }^{11}$ The Supreme Court has laid down that where a legal wrong or legal injury is caused to a person or to a determinate class of person by reason of violation of any constitutional or legal right or any burden is imposed in contravention of any Constitutional or legal provision or without authority of law or any such legal wrong or legal injury of illegal burden is threatened and such person or determinate class of persons, is, by reason of poverty, helplessness or disability or socially or economically disadvantaged position, unable to approach the Supreme Court for relief, any member of the public can maintain an application for an appropriate direction, order or writ in the High Courts under Article 226 and in the case of breach of any fundamental right in the Supreme Court under Article 32 seeking judicial redress for the legal wrong or injury caused to such person or determinate class of persons. D.D. Basu, An Introduction to the Constitution of India, Wadha Company Ltd., 2001.pp. 54-59.

12 The schemes are: (1)the Public Distribution System (PDS); (2) Antyodaya Anna Yojana (AAY); (3) the National Programme of Nutritional Support to Primary Education, also known as "mid-day meal scheme"; (4) the Integrated Child Development Services (ICDS); (5) Annapoorna; (6) the National Old Age Pension Scheme (NOAPS); (7) the National Maternity Benefit Scheme (NMBS); and (8) the National Family Benefit Scheme (NFBS). Essentially, the interim order of 28 th November 2001 converted the benefits of these eight "schemes" into legal entitlements. A ninth scheme, Sampoorna Gramin Rozgar Yojana (SGRY), was not mentioned in this order, but it did figure in the initial list of food-related schemes on which the Supreme Court requested affidavits from the State Governments (on 17 September 2001), and SGRY became the main focus of the next interim order, issued on 8 May 2002. 
observations made by the Supreme Court of India with regard to the MDMS. The highest court of the land has also appointed Food Commissioners to monitor and report periodically on the status of availability to access to food to the poor and marginalized population and the MDMS becomes part of this mechanism as it covers more than 11 crore children across India.

\section{Issues Related to Mid-Day Meal Scheme:}

India has the largest school feeding programme in the world; in 2011, it reached 113.6 million schoolchildren. The Mid Day Meal Scheme (MDMS), the country's national programme launched in 1995, aims to ensure that all children receive primary education and to boost the nutrition of students in primary-school classes. A pivotal Supreme Court ruling in 2001 - the result of a civil action - declared that school feeding was a right of all primary-school children and mandated the provision of cooked midday meals in primary schools. As a consequence, coverage increased nationwide (by more than 10 percent from 2001-2011) although wide regional disparities remain, mainly because of financial constraints at the state level. Nutritional guidelines and food basket quality have improved over time as well.

The MDMS is a good example of a mixed implementation approach with two separate procurement processes: one for food grains, which are subsidized centrally through the governmentowned Food Corporation of India, and one for other foods like fresh fruits or vegetables, for which procedures are established at the state level. Overall responsibility for the programme lies with the Department of School Education and Literacy, while a national steering and monitoring committee monitors the programme. Similar committees also exist at the state, district and local levels. State governments and union territories are responsible for implementation. At the school level, the programme is administered by the village education committee, the school management and development committee, the parent-teacher association or, in some cases, NGOs.

In 2010-11, the combined expenditure of the central government and the state a governments/union territory on the school meals programme was around US $\$ 3,850$ million. Higher enrolment has been observed, particularly among the Scheduled Castes and Scheduled Tribes children (formerly known as "untouchables"). Data on gross primary enrolment rates from 2001-2002 and20072008 confirms a significant rise a Scheduled Castes (103.1 to 132.3 percent for boys, and 82.3 to 116.7 percent for girls)and Scheduled Tribes (106.9 to 134.4 percent for boys and 85.1 to 124 percent for girls).

The nutritional impact, however, has not been evaluated, and the links with health and nutrition could be strengthened considerably better coordination between sectors. The late disbursement of government funds to the implementing agencies is reported to have a negative impact in many areas. ${ }^{13}$ India's food production is enough to eradicate hunger, but the supplies are not evenly distributed and therein lay the crux of the hunger problem. Fifty percent of the world's hungry live in India, with 200 million food-insecure people in 2008 according to the Food and Agricultural Organization. India ranks $66^{\text {th }}$ out of 88 nations on the Global Hunger Index. ${ }^{14}$ Sen $(1977,1981)$ explains this through entitlement approach.

\section{Significance of the Issues:}

A person's entitlement is the alternative sets of commodity bundles that a person can acquire through endowments (legal or physical) or exchange entitlement mapping. If a person is legally alienated from land, or a person loses physical ability to work, then it might lead to hunger and starvation even if

\footnotetext{
${ }^{13}$ MS Swaminathan Research Foundation of India. 2011. The school feeding programme in India: a country profile case study. London, Partnership for child development.

${ }^{14}$ Food and Agricultural Organization Report of 2008
} 
there is overall growth in food grain production. Similarly, drop in the relative price of goods that the person produces, fall in real wages, and rise in relative prices of food grains, adversely affects the exchange entitlement mapping for the individual, resulting in hunger and starvation. Similarly, merely being a food producer does not ensure access to food. Access to food can be achieved through legal and economic entitlement. Legal entitlement involves ownership right to the food produced. Economic entitlement can be ensured by creating employment opportunities, ensuring minimum wages, stabilizing food prices, and facilitating access to food through the Public Distribution System (PDS).

Entitlements can be realized if there is availability of food. However, availability is only a necessary condition. Food production not only ensures food availability (supply side), but it also improves entitlement through employment creation and subsequent income generation (demand side). Decline in food production does not necessarily imply decline in entitlement provided there are alternative employment and livelihood opportunities. Sheriff et al. (2004) have suggested four different types of food and nutrition insecurities. These are (a) Chronic Food insecurity: caused due to energy deficit for a prolonged period of time.

Policy interventions to eradicate chronic food insecurity calls for both demand side, purchasing power, social security measures, and supply side interventions (agricultural policies, export-import policies, distribution policies); (b) Nutritional food insecurity: caused due to the deficiency of micronutrients. Polices involve food fortification and their supply through Public Distribution System (PDS), providing micronutrients to children below 5 years of age through Integrated Child Development Scheme (ICDS); (c) Absorption food insecurity: caused due to the non-availability of portable water and poor sanitation. Policies involve providing basic infrastructure, and creating awareness; (d) transitory food insecurity: caused due to natural calamities. Policies involve appropriate disaster management.

Thus hunger can be a result of host of factors and these factors can be arranged in a sequence that runs from food self-sufficiency, food availability, food entitlement, and nutritional adequacy. Policy corrections can be made once the predominant source is identified. India has been implementing several programmes that seek to address each of the above factors that impact hunger. The agriculture policy addresses the concerns of food availability and self-sufficiency. The poverty alleviation strategy and programmes that of food entitlements, and several specific programmes addresses the issue of nutritional adequacy. As Viswanathan (2014, Background Paper for IPPR 2014) points out social and cultural aspects that govern intra-household distribution of consumption, determine the status of women, which has implications for feeding and healthcare practices for infants and children. This has to be addressed in the short term mainly by creating awareness and demonstrating the impact of best practices, and in the longer term by educating and empowering girls.

In India, virtually all public programmes at the central and state level have some element of poverty and hunger eradication. Therefore, it is important that at the state and district-level there is an integrated and coordinated approach to the implementation of the public programmes. In regions where there is a large burden of hunger, the focus has to be on involving the local community in service delivery and oversight. Synergy and convergence between different programmes at the grassroots level can ensure a more holistic and result driven approach to eradication of hunger on a sustainable basis. Though the scheme is considered to be popular and successful, it is faced with several problems. In 2005-06, of the grain allocated by the Central Governments based on estimates of enrollments and attendance, the state governments lifted only $76.8 \%$. This implies that either all the institutions or children entitled to the MDM were not fully covered. It could also imply that providing insufficient quantity of food compromised the stipulated quality of the meal or it could also mean that meals were not provided on all working days.

The other important problems relating to the scheme were reflected in the performance audit report on the MDMS by the CAG of India (CAG: 2008). This report found that many states resort to over 
reporting the enrolment while estimating their demand for funds. The provision for the regular monitoring and evaluation as well as inspections in the scheme designed was not effectively followed nor any lessons learned and measures initiated to correct the observed flaws. It was also reported that the undesirable involvement of teachers in supervising the cooking and serving of the meal resulted in detraction from their teaching responsibilities through less of teaching hours. The other problems that the scheme is faced with are the lack of adequate infrastructure for the clean and hygienic functioning of the programme, improper and unsafe storage of food and other cooking ingredients, as well as low and adulterated quality of materials used. This serious neglect of quality and hygiene has recently even led to the sickness and death of school children.

The issue of classroom hunger is one of the primary reasons for the implementation of MDMS in Tamil Nadu and later on in India. Classroom hunger is prevalent across India due to the extreme poverty in the country and households struggling to even have one-square meal a day. The MDMS's humble vision is to make them to attend school on a regular basis and provide them with a free meal throughout their period in school (Saxena: 2003, Shiva Kumar: 2003, Vijayaraghavan: 2004, Dreze: 2004). MDMS is also significant to improve enrolment in schools (Kanam: 2003, Devendra: 2003, Dogra and Dogra: 2003, Dreze and Goyal: 2003, Sen: 2002, Jaitley: 2002). John Harris (1986) has given some reasons of justification for the scheme, they are, political, nutritional, employment, welfares, health, education and social. Harris focuses on the theme of education as it is expected to increase enrolment of children at the age of five and of non-starters and girls above this age. ${ }^{15}$

\section{Findings:}

The MDMS in its present version has ventured out towards complete servicing of the child and the mother from the time of its creation in its womb. This comprehensive promotion of education and health for all children combines the twin-fold objectives of Universalization of Elementary Education and employment generation in the urban and rural areas of the country and state. A serious failing of many supplementary feeding programmes now operating is that the real objectives have not been sufficiently considered in programme design, that programmes would be differently planned if objectives other than those stated in policy documents were taken into account. This may aid in understanding of the further question of the specific design of the nutrition intervention, why it was not differently planned.

First, the nutritional justification is to guarantee a free meal every day providing one-third of nutritional requirements. The stores and outlets of the State Civil Supplies Corporation, many of which are co-operatives administer supplies. Secondly, the employment justification is to offer preferential employment opportunities to destitute and/or widowed women in each of the feeding centres; to liberate the mothers of children above the age of two for work outside the house; to increase employment under the National Rural Employment Guarantee Programme; kind payment scheme to create physical infrastructure. Employment was provided in 1985 for 1, 80,118 people; 88\% women, dispersed over some 63,000 feeding centres. Employment is said to discriminate in favour of women, destitute and widows.

Thirdly, the welfarist justification is that the scheme targeted by age and by income for needy children below the poverty line and it is an income supplement to households at a period in the life-cycle of the family, when dependency ratios are maximized as it provides employments for recruits from the pool of women. When there are multiple objectives, few of which are reducible to a common single

\footnotetext{
${ }^{15}$ At various times it was also stated that the scheme would regularize school attendance, reduce rates of dropping out from school, inspire nutrition education, contribute to nutritionally valuable practical activities such as the planting of food trees and educate about environmental sanitation; in turn, enabling diffusion of such messages to other members of the beneficiaries families. Barbara Harris, "Meals and Noon-Meals in South India: Food and Nutrition Policy in the Rural Food Economy of Tamil Nadu State", Development Studies Occasional Paper No 31, School of Development, Studies, University of East Anglia, October, 1986, P-17.
} 
economic numeraire, such as cost, the measurement of success is amenable to subjective trade-off. It is regarded as a nutrition intervention and the MDMS is the largest nutrition intervention of its kind in the world at present.

The social implication of this scheme is very encouraging as it urges children of different castes to integrate by inter-dining and to accept food cooked by people of marginalized communities. Children belonging to all communities freely eat the food cooked and served by other people with regard to preschool children irrespective of their community and religion, they learn to move, mingle and eat and learn together thus equipping themselves from an early age to be true citizens of India, transcending all differences and divisions, the socio-economic transformation of all underprivileged is being achieved. In this respect it has been described as the harbinger of new social order and as having the potential to bring about the socio-economic transformation of the underprivileged. The scheme would have to fail on all the above counts of justification for it to be completely discredited.

\section{Suggestion:}

This research study highlights the overall success of the Mid-Day Meal Scheme in Tamil Nadu and also the scheme in its original form being replicated all over India. This is a good example of a policy, which has consistently delivered the service made out as the sole objective when it was designed and has been allowed to mature over a period of time that today it has become almost synonymous with primary education. This research study helped to understand the administrative system used to service the huge number of beneficiaries. In this regard some areas where there is scope for improvement were found in terms of those who administer this scheme and also the beneficiaries of this Mid-Day Meal Scheme.

The children who are beneficiaries of this scheme, it is felt, need an outdoor play area in the form of a small park or garden adjoining their place of study. This form of space utilization ensures children some outdoor activity in the form of games etc. further physical activity is important in the growth of a child. The Anganwadis personnel are actually pre-school teachers but since their job specification involves teaching, preparing teaching aid, census work of the community allotted to them their timings are stretched. This has a direct bearing on their time spent with the children. A suggestion made in this regard is for provision of readymade teaching aid, which enables less time in preparing them and more time can be spent with the children. The working staff and helpers appointed for each school are insufficient with the steady increase in the influx of the students. There is a need for additional administrative staff to be appointed, which would help in generating more employment and also provide adequate personnel for the effective administration of this scheme.

Another area of concern is the aspects of nutrition in the meal served to the children across India, Tamil Nadu and in the research area pertaining to this study i.e. Chennai City, is the field study highlighted the emphasis on calorie content of the school lunch rather than on the actual nutritious value the lunch provides to the children. Tamil Nadu government stipulates the menu to be provided for the children by the school. One suggestion in this area is to slowly increase the share of locally grown, inexpensive and available millets and pulses in the mid-day meal scheme. The cost and availability of rice and wheat for such a large scale feeding programme at a subsidized rate brings to the issue stability and consistency in delivery of this scheme. Commodity and food prices are highly instable and volatile. The Indian government has recently secured its right to minimum support price which is essential aspect of food subsidy in the World Trade Organisation (WTO) negotiations in 2014. Hence, an alternate and more healthier and nutritious option is the need of the hour for the successful continuation of the programme in the long run.

The idea of serving millet porridge, instead of a rice based lunch is a good workable solution for managing the price-rise in procuring rice and wheat at the subsidized rate for the school lunch programme by the respective State Governments. Also, this way the local Panchayat, can be allotted the task of 
locally growing these millets, which very less intensive crops interms, of land, water, pesticides etc. The millets were part of our ancient food habits before the introduction of rice and wheat into our food systems. They are very organic crops by nature and require no pesticides and very less water. This given the monsoon based agriculture system of India, is ideal as some amount of rain is enough for these millets to grow in 3 or 6 months time. They are not pesticide and water intensive like paddy crops. This suggestion will have a trickle down effect by not only actually providing children with nutritious meal for lunch but save the programme being put under pressure by any external funding agency or Government itself in the face of any food price rise or instability in continuation of food subsidy in India. Also, right now the mid-day meal scheme by nomenclature provides for one cooked meal a school day, i.e. lunch for the kids. The millet based lunch programme will also provide an opportunity to start a concept of breakfast for these kids before the start of school.

The breakfast model can be based on our highly nutritious millets, for example Horse Gram (Ragi) millet ball breakfast with locally produced greens and pulses. We all know that children are the future of the nation. Our leaders have emphasized that India is scoring in the race to having the youngest population till the year 2050. The question is whether this population will be equipped mentally and physically apart from education and skill-sets to provide the human resource solution that the global village will require. Food crisis is one such area that is being predicted by several researchers, organisations and models. The schools are considered to be a place of learning, honing skills etc. This mid-day meal scheme can be used as this opportunity to continue the learning to life-skills for these children which will help them realize the importance of environment.

The suggestion is to start a kitchen garden in each school. Each school can start their very own kitchen garden to suit their enrolment and grow vegetables, greens essential for the cooking within their own premises. The Government can set-up a pilot study and a feasibility study to work this model in Chennai and Tamil Nadu to begin with. This way we can create grain bank in the local Panchayat in each block, village or area and also create a vegetable market for each school area all year round to provide for the children without having to procure from markets at a subsidized rate. The children who attend school will benefit hugely from this wholesome learning by doing. This suggestion if undertaken earnestly will provide a local and economically workable solution for every Gram Panchayat, Block, District, State in the long term.

The concept of minimum government and maximum governance promoted by the present government of India will have to start looking at alternate solutions to become self-sufficient in providing policy solutions and entitlements to poor and marginalized sections of this country. The Mid-Day Meal Scheme provides this opportunity to turn the problem of providing into an opportunity to become selfsufficient at the local level itself. This in turn will take effect as a bottoms-up approach in terms of taking reference to a economic model. Another suggestion from the personnel side is a need for more persons to be appointed in the cadre of supervisors to ensure there is proper and adequate supervision of the administration of the scheme. The personnel appointed under the Chief Minister's Nutritious Meal Programme have all remained in the same cadre from the time of their appointment. This kind of stagnation in their present scale of pay without due promotional opportunities is a deficiency, which can be looked into by the administration.

A massive feeding programme of this type requires stringent conditions of hygiene and cleanliness as it is meant for children. Hence, proper care should be taken to maintain the kitchen and other utensils in a hygienic manner. To ensure the environmental hygiene, the workers and staff should be given proper training in public health and hygiene. Training and development of personnel is a brighter side with the organization giving them three times training per month. They are involved in teaching and feeding the children, the overall development of the child's general knowledge, the nutritional and pre- 
natal care and understanding of the mothers. The impact of the noon meal scheme has a direct bearing on school enrolment and an important auxiliary advantage is the creation of widespread employment, besides the social implications of creating communal harmony. The scheme has brought about a significant change in the social environment in rural areas. In that sense, it will be ironically right to point out that the policy went beyond its brief. Yet, the current scheme needs to continue with improvements in the provision of quality nutrition and complete nutrition education as part of primary education system.

\section{Conclusion:}

The research study carried out has revealed that the programme needs to be strengthened with regard to physical infrastructure, assistance and incentives for workers, nutrition education of the parents, community and the beneficiaries, involvement of leaders and nutritional assessment of the participating children. A system of built-in evaluation can be created so that periodical compilation of the observations will help the governments to evaluate the outcomes of the heavy investment it is making in feeding and educating the poor and needy section of its population. This research study has been an enriching experience and has led to the realization that the Mid-Day Meal Scheme is a wise investment in human resources development, which is essential for national development. Over a period of time, it was seen that the scheme has remained a mere governmental programme and the implementation has lacked professionalism and effectiveness among the implementing agencies. In other words, the prime objectives of the scheme, namely, nutrition and education, have grossly been undermined across the states. While a few states have initiated many reforms to strengthen the scheme, a large number have lagged behind indicating different socio-economic factors like lack of revenue and little interest taken by the public.

Now the MDM is a major scheme which is implemented in all the states in India, has come across many ups and downs since its introduction. The scheme suffers from various problems like distribution of dry ration, nutrition, false evidence of attendance, teacher's hesitance to carry out the scheme in the school and corruption. Yet after the Public Distribution System (PDS), MDM is going to be the largest school feeding programme in the world. Ensuring a cooked and nutritious MDM in primary schools is rapidly becoming a broad-based people's movement where it is expected that organizations and individuals around the country are to take part in facilitating and protecting the child's right to food through MDMS. Foremost among various issues that need to be taken care of is giving importance to its nutritional aspect which has been a major challenge since its inception. The success of the programme is dependent on continued public participation and vigilance as well as sustained political interest in it. The experience so far clearly shows that MDMS have much to contribute to the well-being of the future of Indian children.

\section{Reference:}

This article is a refinement on the research subject by the author of his previous research as published at:

http://www.worldwidejournals.com/international-journal-of-scientific-research(IJSR)/file.php?val=April_2016_1459512356_39.pdf 